\title{
PENGASUHAN ANAK MENURUT HUKUM ISLAM
}

\author{
Abdul Basith Junaidiy \\ Fakultas Syariah dan Hukum UIN Sunan Ampel Surabaya. \\ Email: basithjunaidy71@gmail.com
}

\begin{abstract}
Divorce between husband and wife has consequences to child. Parental obligations to a child are not limited to the time of marriage, but continuing even if their marriage has been broken. The problem that arises is who between the two parents is more worthy of parenting. In principle, Islam provides provisions that mother is more worthy to nurture for a reason that mother is usually more loving than father. However, Islam as a religion with a rabmatan lil'alamin mision, sets a universal principle, namely the main requirement of a caregiver is to have an attitude of trust and ability. The term of trust (amanab) includes a good moral and not to damage the child's belief. Even, the non-Muslim caregiver is allowed as long as she is not concerned about damaging the child's belief. The term of "ability" requires a caregiver to spend time with the child. By this reason, the mother's position, for example, as a caregiver, can be replaced by a father if she is not trustful. Law on Marriage and Islamic Law Compilation (KHI) give strong emphasis on the trustworthy provision of a caregiver in the matter of maintenance and moral education to child. The Religious Courts is authorized to deprive the child's custody of the untrust caregiver. In the matter of difference in religion, the Religious Courts is also authorized to decide whether it affects to the benefit of a child or not.
\end{abstract}

Keywords: Parenting and Islamic law.

Abstrak: Perceraian yang terjadi antara suami isteri mengakibatkan konsekuensi terhadap anak. Kewajiban orang tua terhadap anak tidak terbatas pada saat perkawinan masih utuh, akan tetapi terus berlangsung meski perkawinan mereka telah putus. Persoalan yang muncul adalah siapa di antara kedua orang tua itu yang paling layak untuk melakukan pengasuhan. Secara prinsip, Islam memberikan ketentuan, bahwa ibu lebih layak untuk mengasuh karena alasan, bahwa ibu biasanya lebih memiliki kasih sayang di banding ayah. Namun, Islam sebagai ajaran yang memiliki misi rabmatan lil alamin, menetapkan prinsip universal dalam hal ini, yaitu syarat utama pengasuh anak adalah memiliki sikap amanah dan memiliki kecakapan. Syarat amanah meliputi sikap moral yang baik dan tidak merusak agama anak. Pengasuh non-muslim diperkenankan asal tidak dikhawatirkan merusak agama anak. Syarat kecakapan menuntut kesediaan pengasuh meluangkan waktu untuk anak. Atas dasar itu, posisi ibu, misalnya, sebagai pengasuh bisa saja digantikan ayah jika ia tidak amanah. Undang-Undang Perkawinan dan KHI memberikan tekanan yang kuat terhadap ketentuan dapat dipercayanya pengasuh dalam urusan 
pemeliharan dan pendidikan akhlak anak asuhnya. Pengadilan Agama diberi wewenang untuk mencabut hak hadanah dari pemegang hadanah yang tidak amanah. Dalam masalah perbedaan agama, Pengadilan Agama juga berwenang memutuskan apakah perbedaan agama tersebut berdampak kemaslahatan untuk anak asuh atau tidak.

Kata Kunci: pengasuban, bukum Islam

\section{Pendahuluan}

Ketika calon suami dan calon isteri telah melaksanakan akad nikah sesuai dengan syarat dan rukun yang telah ditetapkan oleh hukum Islam, maka keduanya telah terikat oleh ikatan perkawinan yang sah. Dari perkawinan tersebut, muncul hak yang akan diterima oleh masing-masing pihak dan kewajiban yang harus diberikan kepada pihak lain. Di samping itu, mereka juga harus berupaya mewujudkan tujuan-tujuan utama perkawinan, seperti melanjutkan keturunan, menciptakan keluarga yang diliputi cinta (mawaddah) dan kasih sayang (rahmah), dan mendidik anak sebagai generasi masa depan muslim yang sempurna dan lain-lain. ${ }^{1}$

Sebagai agama yang mengatur segala bidang kehidupan umat manusia, Islam telah menetapkan hak-hak dan kewajiban mereka selaku suami isteri, baik secara eksplisit maupun implisit di dalam dua sumber utamanya, yaitu al-Qur'an dan as-Sunnah. Hak adalah sesuatu yang merupakan milik atau dapat dimiliki oleh masingmasing suami atau isteri yang diperoleh dari perkawinannya. Hak tersebut hanya dapat dipenuhi ketika pihak lain membayarnya atau memenuhinya. Namun, hak bisa juga dihapus ketika yang memilikinya rela haknya tidak dibayar atau tidak dipenuhi oleh pihak lain. Sedangkan kewajiban adalah hal-hal yang wajib dipenuhi atau diadakan oleh masing-masing suami atau isteri untuk memenuhi hak pihak lain. ${ }^{2}$

Pasal 45 ayat 1 dan 2 Undang-Undang No. 1 Tahun 1974 Tentang Perkawinan menjelaskan salah satu kewajiban yang harus dilakukan kedua orang tua terhadap anak-anaknya. Pasal tersebut berbunyi : (1) kedua orang tua wajib memelihara dan mendidik anak

1 Kamal Muchtar, Asas-asas Hukum Islam Tentang Perkawinan, (Jakarta : Bulan Bintang, 2004), 126.

${ }^{2}$ Ibid. 
mereka sebaik-baiknya dan (2) kewajiban orang tua yang dimaksud dalam ayat (1) pasal ini berlaku sampai anak itu kawin atau dapat berdiri sendiri, kewajiban mana berlaku terus meskipun perkawinan antara kedua orang tua putus.

Pasal tersebut menegaskan salah satu dari kewajiban suami isteri, yaitu memelihara, merawat dan mendidik anak-anak sampai mereka dapat mandiri dalam menghadapi realitas kehidupan. Kewajiban ini tidak hanya terbatas ketika mereka masih terikat dalam perkawinan, akan tetapi juga dibebankan kepada orang tua ketika mereka sudah putus dari ikatan perkawinan. Masalah ini dalam literatur fikih, dikenal dengan hadanah.

Demi kepentingan tersebut, masing-masing suami isteri dituntut mampu menahan diri untuk tidak melakukan hal-hal yang membawa kepada keretakan rumah tangga. Kedudukan mereka adalah sama. Masing-masing harus menyadari posisinya. Kelalaian salah satu pihak dalam menunaikan kewajibannya berarti menelantarkan pihak lain yang pada gilirannya akan mengakibatkan keretakan dalam rumah tangga. Bilamana keretakan tersebut berujung pada perceraian, maka yang menjadi korban utamanya adalah anak keturunan mereka.

Pertanyaan yang muncul kemudian adalah, siapa yang bertanggung jawab terhadap kelangsungan hidup dan pendidikan anak keturunan mereka. Dalam hal ini, ada beberapa kemungkinan. Pertama, ayah dan ibu tidak ambil peduli dengan nasib anak-anaknya. Kedua, ayah dan ibu saling berebut untuk mengasuh anak mereka. ketiga, ayah dan ibu saling berbagi dalam mengasuh anak mereka. Walaupun demikian, tidak jarang cara penyelesaiannya dilakukan melalui jalur hukum.

Atas dasar itu, ada beberapa pertanyaan yang perlu dijawab berkaitan dengan pengasuhan anak: Pertama, apakah hadanah ini merupakan hak anak atau hak suami-isteri, kedua, siapa di antara suami dan isteri yang lebih berhak mengasuh anak, ketiga, syaratsyarat apa yang harus dipenuhi untuk melakukan tugas tersebut, keempat, bagaimana urutan orang yang berhak melakukan hadanah (hadin/hadinab), dan Kelima, bagaimana undang-undang Perkawinan tahun 1974 dan KHI mengaturnya. 


\section{Pengertian al-Hadanah}

Secara etimologis al-hadanah diambil dari kata al-hidn, yang berarti rusuk, yakni mengumpulkan ke rusuk. Kemudian kata Hadanah dipakai sebagai istilah dengan arti pengasuhan anak. Dimaknai demikian karena seorang ibu yang mengasuh atau menggendong anaknya, seringkali meletakkan pada sebelah rusuk atau dalam pangkuan sisi sebelah rusuk sang ibu. ${ }^{3}$

Menurut Wahbah Zuhaili, hadanah adalah mendidik dan memelihara orang yang tidak bisa mandiri dalam menangani urusan-urusan pribadi dari hal-hal yang tidak disukainya. Orang yang tidak bisa mandiri itu misalnya karena ia belum tamyiz, seperti anak kecil dan orang gila. Tindakan tersebut dilakukan dengan cara melindungi segala urusan, mengatur makanan, minuman, pakaian, tidur, mandi, membersihkan diri, mencuci baju pada umur tertentu dan lain sebagainya. ${ }^{4}$ Menurut Sudarsono, hadanah adalah merawat dan mendidik seseorang yang belum mumayyiz atau kehilangan kecerdasannya, karena mereka tidak bisa mengerjakan keperluannya sendiri. ${ }^{5}$

Dalam peristilahan fiqih, ada dua kata berbeda yang seringkali dimaksudkan untuk satu makna yang sama, yaitu kata kafalah dan hadanah. Maksud keduanya dalam arti sederhana adalah pemeliharaan atau pengasuhan. Dalam arti yang lebih lengkap, adalah pemeliharaan anak yang masih kecil setelah terjadinya putus perkawinan. ${ }^{6}$ Menurut al-Shan'ani, yang dimaksud hadanah adalah mengasuh seseorang (anak) yang tidak bisa mandiri, mendidik dan memeliharanya untuk menghindarkan dari segala sesuatu yang dapat merusak dan mendatangkan madarat kepadanya. ${ }^{7}$

3 Wahbah al-Zuhaili, Al-Fiqh al-Islami wa Adillatuh, (Damsyiq : Dar al-Fikr, 1989), VII : 717. lihat juga Kamal Muchtar, Asas-asas Hukum Islam Tentang Perkawinan, 126.

${ }^{4}$ Wahbah Zuhaili, Al-Fiqh al-Islami Wa Adillatuh, 718.

${ }^{5}$ Sudarsono, Kamus Hukum, (Jakarta : Rineka Cipta, 1992), 433.

${ }^{6}$ Amir Syarifuddin, Hukum Perkawinan Islam di Indonesia, Jakarta : Prenada Media Group, 2006), 327.

${ }^{7}$ Al-Shan'ani, Subul al-Salam, juz 3, (Kairo : Dar Ihya al-Turats al-'Araby, 1379 H/1960 M), 227 
Pemeliharaan anak, pada dasarnya menjadi tanggung jawab kedua orang tua. Hal ini meliputi berbagai hal: masalah ekonomi, pendidikan dan segala sesuatu yang menjadi kebutuhan pokok anak. Dalam Islam, tanggung jawab ekonomi berada di pundak suami sebagai kepala rumah tangga, meski pun tidak menutup kemungkinan istri dapat membantu suami dalam menanggung kewajiban ekonomi tersebut. Karena itu, yang terpenting adalah kerjasama dan tolong menolong antara suami dan istri dalam memelihara dan mengantarkan anak hingga usia dewasa. UndangUndang Perkawinan dan Kompilasi Hukum Islam tidak mengatur secara terperinci masalah tersebut, karena tugas dan kewajiban memelihara anak, inheren dengan tugas dan tanggung jawab suami yang sekaligus menjadi bapak bagi anak-anak. ${ }^{8}$

Menurut Satria Efendi, istilah hadin atau hadinab dan wali memiliki arti yang berdekatan. Hadin dimaknai dengan tugas menjaga dan mengasuh serta mendidik bayi atau anak kecil sejak ia lahir sampai bisa melakukan hal-hal sederhana, seperti makan sendiri, berpakaian sendiri dan bisa membedakan antara yang bermanfaat dan berbahaya bagi dirinya sendiri . Bila diukur dengan umur, maka sampai ia berumur tujuh atau delapan tahun. Pada masa sebelum itu, anak umumnya belum bisa mengatur diri sendiri dan belum bisa membedakan mana yang bermanfaat dan berbahaya bagi dirinya. Sedangkan istilah wali digunakan untuk orang yang melakukan pemeliharaan atas diri anak-anak semenjak berakhir periode hadanah sampai ia balig berakal, atau sampai ia menikah bagi anak perempuan. Dengan demikian, tugas wali adalah menyambung dan menyempurnakan pendidikan anak yang telah dimulai pada waktu hadanah serta bertanggung jawab atas kelangsungan hidup dan pemeliharaan anak sampai ia akil balig dan mampu berdiri sendiri. Wali juga berarti orang yang diberi wewenang untuk memelihara harta anak kecil serta mengatur pembelanjaannya. ${ }^{9}$ Hal ini sesuai dengan pendapat Abu Zahrah

${ }^{8}$ Ahmad Rofiq, Hukum Perdata Islam di Indonesia, (Jakarta : PT. Rajagrafindo Persada, 2015), 189

9 Satria Effendi M. Zein, Problematika Hukum Keluarga Islam Kontemporer, Jakarta: Prenada Media, 2004), 220. 
yang membagi perwalian terhadap anak kecil semenjak ia dilahirkan menjadi 3 bagian, yaitu : hadanah

Pertama, perwalian terhadap pendidikan dasar anak, yaitu

Kedua, perwalian terhadap perlindungan diri anak, yang berlangsung sejak anak melewati umur hadanah sampai ia balig. Bagian ini berlaku juga bagi orang gila, orang yang mengalami keterbelakangan mental, perempuan belum menikah (perawan) dan janda yang dikhawatirkan tidak dapat menjaga dirinya sendiri.

Ketiga, perwalian terhadap harta anak, yang berlaku pada anak-anak, orang gila, orang yang mengalami keterbelakangan mental, orang yang boros, orang yang suka lupa, dan orang-orang lemah. $^{10}$

Dengan demikian, hadanah adalah pengasuhan dan pendidikan terhadap anak kecil yang belum bisa mengurus urusannya sendiri. Hadanah dilakukan setelah terjadinya perceraian sampai mereka mampu mandiri dalam menghadapi realita kehidupan.

\section{Pemilik Hak Hadanah}

Fuqaha berbeda pendapat dalam menetapkan siapa yang berhak terhadap hadanah. Dalam hal ini ada tiga pendapat yang berkembang, yaitu :

Fuqaha Hanafi dan pendapat yang masyhur dalam mazhab Maliki menyatakan, bahwa hadanah merupakan hak hadin (pengasuh). Oleh karena itu, ia berhak untuk melepaskan haknya meskipun tanpa adanya imbalan. Seandainya hadanah merupakan hak selain pengasuh, niscaya tidak akan lepas dengan adanya pelepasannya. Ia tidak dapat dipaksa untuk melaksanakan pengasuhan apabila ia tidak mau melaksanakan haknya. Sebaliknya, ia berhak memaksa si anak supaya mau diasuh, jika anak itu menolak untuk diasuh olehnya. Pendapat ini tidak konsisten karena mereka juga berpendapat bahwa pengasuh dapat dipaksa melaksanakan asuhan apabila tidak ada pengasuh lain yang akan mengasuh anak tersebut.

${ }^{10}$ Muhammad Abu Zahrah, Tanzim al-Islam li al-mujtama', (Mesir : Dar al-fikr al'Arabiy,tt), 88. 
Sebagian fuqaha berpendapat bahwa hadanah merupakan hak anak. Jika anak melepaskan hak tersebut, maka hak itu akan terlepas. Pengasuh dapat dipaksa untuk melakukan pengasuhan, apabila ia tidak mau melaksanakan kewajibannya. Sebaliknya jika anak tidak mau diasuh oleh pengasuhnya, maka pengasuh tidak dapat memaksa anak itu agar mau diasuh olehnya. Kelompok ini dipandang tidak konsisten karena mereka juga berpendapat, bahwa pengasuh tidak dapat dipaksa melaksanakan pengasuhan anak, apabila ada pengasuh lain yang juga berkewajiban mengasuh anak itu.

Ulama Muhaqqiqin berpendapat, bahwa badanah terkait dengan tiga hak: yaitu hak ibu pengasuh, hak anak dan hak ayah atau orang yang menduduki kedudukannya. Jika ada kemungkinan untuk mengkompromikan ketiganya, maka hal itu harus dilakukan. Namun jika terjadi pertentangan, maka hak anak harus didahulukan di atas hak-hak lainnya. Anak asuh berhak mendapatkan pengasuhan dari pengasuhnya karena ia memerlukan pemeliharaan, bimbingan, petunjuk, dan pelajaran yang sangat diperlukan dalam menghadapi realitas kehidupan di masa yang akan datang. Demikian pula, ibu dan ayahnya berhak atas pengasuhan anaknya, karena mereka adalah orang yang paling menginginkan kebahagiaan dan kemaslahatan si anak di masa depan. ${ }^{11}$

Pendapat ketiga di atas mengandung beberapa konsekuensi sebagai berikut: Pertama, Ibu pengasuh dapat dipaksa untuk melakukan kewajiban hadanah jika tidak ada yang lain. Kedua, Ibu pengasuh tidak boleh dipaksa untuk melakukan kewajiban hadanah, jika ada orang lain yang dapat melakukannya dengan syarat anak yang diasuh tidak mengalami kemadaratan. Ketiga, jika seorang perempuan melakukan khulu' terhadap suaminya dengan syarat perempuan itu akan meninggalkan anak di bawah asuhan suami, maka kbulu' tersebut sah, tetapi syaratnya batal karena badanah merupakan hak anak, di mana ia bisa bersama ibunya selama membutuhkan. Keempat, ayah tidak diperkenankan

11 Wahbah al-Zuhaili, Al-Figh al-Islami wa Adillatub,718-9. Lihat juga Kamal Muchtar, Asas-Asas Hukum Islam Tentang Perkawinan, 141. 
mengambil anak dari ibu pemilik hak hadanah, lalu memberikannya kepada orang lain kecuali karena ada alasan yang bisa diterima menurut syara'. Kelima, jika perempuan yang menyusui bukan perempuan yang melakukan hadanah terhadap anak, maka ia harus melakukan kegiatan penyusuan di hadapannya, agar hak pengasuhannya tidak hilang. ${ }^{12}$

\section{Pihak yang Lebih Berhak Melakukan Pengasuhan}

Melakukan hadanah terhadap anak yang orang tuanya telah bercerai adalah wajib sebagaimana wajib juga memeliharanya, selama mereka masih terikat oleh tali perkawinan. Hal ini didasarkan pada ayat-ayat al-Qur'an ${ }^{13}$ dan hadis-hadis Nabi.

Berkaitan dengan siapa di antara ayah atau ibu yang lebih berhak untuk melakukan tugas hadanah anak-anak, ada beberapa riwayat dalam hadis Nabi yang mengindikasikan beberapa hal berikut ini, yaitu :

Pertama, jika anak-anak belum mencapai umur tamyiz, maka ibu yang paling berhak melakukan pengasuhan. Hal ini didasarkan riwayat Abu Dawud dari Abdullah ibn Amr, bahwasannya ada seorang perempuan melapor kepada Rasulullah, bahwa mantan suami yang telah mencerainya bermaksud mengambil anak yang berada dalam pengasuhannya. Rasulullah menyelesaikan masalah ini dengan menyatakan, bahwa perempuan itu lebih berhak untuk mengasuh anaknya sampai ia menikah dengan orang lain. ${ }^{14}$

Kedua, jika anak-anak sudah mampu memenuhi kebutuhannya sendiri, dalam arti sudah mumayyiz, maka ia diperkenankan untuk memilih antara ibu atau ayahnya. Hal ini sesuai dengan hadis Nabi yang diriwayatkan oleh imam Ahmad dan empat imam hadis lainnya yaitu Abu Dawud, at-Tirmizi, anNasa'i dan Ibn Majah. Abu Hurairah meriwayatkan adanya perempuan yang melaporkan, bahwa mantan suami yang telah menceraikannya mengambil anak yang berada di bawah pengasuhannya. Mereka bertiga: ibu, ayah dan anak kemudian dihadirkan di hadapan Rasululah. Lalu ia menyuruh anak tersebut

12 Wahbah al-Zuhaili, Al-Figh al-Islami wa Adillatuh, 718-9.

${ }^{13}$ Lihat al-Qur'an $66: 6$, dan $2: 233$.

14 Abu Dawud, Sunan Abu Dawud, Juz II, (Libanon : Dar al-Kutub al-'Ilmiyyah, 1996), 525. 
memilih salah satu dari ibu dan ayahnya. Anak itu, pada akhirnya, menggandeng tangan ibunya. ${ }^{15}$

Diriwayatkan juga, bahwa Umar ibn Khattab telah menceraikan isterinya, perempuan dari kalangan Ansar, setelah melahirkan seorang anak laki-laki yang bernana Asim. Ketika ia melihat Asim di suatu gang, ia mengambilnya. Kemudian neneknya, ibu dari ibunya, menyusul Umar. Mereka berdebat di hadapan Abu Bakar as-Siddiq. Abu Bakar memberikan anak tersebut kepada neneknya seraya berkata kepada Umar al-Faruq: "Bau Ibunya, elusannya, usapannya, dan keringatnya adalah lebih baik daripada madu yang ada padamu". ${ }^{16}$ Pada riwayat lain, Abu Bakar menyebutkan dasar keputusannya: "Ibu itu cenderung (kepada anak) lebih halus, lebih pemurah, lebih penyantun, lebih baik, dan lebih penyayang dan ia lebih berhak atas anaknya selama ia belum kawin (dengan laki-laki lain)". ${ }^{17}$

Ketiga, jika ternyata pilihan anak tersebut kurang tepat, maka Rasulullah mendoakan semoga Allah merubah pilihan tersebut ke arah pilihan yang lebih tepat. Hal ini didasarkan pada hadis Nabi yang diriwayatkan oleh Abu Dawud yang menceritakan kasus Rafi' ibn Sinan yang ketika masuk Islam tidak diikuti oleh isterinya yang tetap memilih menjadi seorang musyrikah. Keduanya mempunyai anak. Untuk memutuskan siapa yang lebih berhak untuk mengasuh anak tersebut, Rasulullah menghadirkan masing-masing pihak : ibu, ayah dan anaknya. Waktu itu si anak memilih ibunya yang nonmuslim. Rasulullah tidak menyetujui pilihan anak tersebut. Lalu Rasulullah berdoa semoga Allah memberi petunjuk terhadap anak tersebut. Akhirnya, anak itu berubah sikap dan kemudian memilih ayahnya yang telah masuk Islam. ${ }^{18}$

Berdasar riwayat-riwayat di atas, nampak bahwa hadanah merupakan hak ibu bukan bapak. Akibatnya, secara analogis (qiyas), para perempuan lebih didahulukan atas para laki-laki dan kerabat

15 Jalaluddin al-Suyuti, Syarh Sunan an-Nasa'I, (Beirut : Dar al-Kutub al-Ilmiyyah, 1988), V : 185-6

16 Muhammad Abu Zahrah, Abwal al-Syakhsyiyyah, (Mesir : Matbaah As-Sa'adah, 1957), 474.

${ }^{17}$ Kamal Muchtar, Asas-asas Hukum Islam Tentang Perkawinan, 141.

18 Satria Effendi M. Zein, Problematika Hukum Keluarga Islam Kontemporer, 182. 
ibu didahulukan atas kerabat bapak. Meskipun demikian, hak hadanah yang diberikan pada perempuan harus didasarkan pada hubungan mahram. Sebab hanya hubungan yang bersifat kerabatmahram yang menjadi dasar timbulnya hak dan kewajiban dalam banyak masalah syar'iyyah. Hubungan tersebut lebih kuat dan lebih menunjukkan kasih sayang. Karena itu, hubungan ini menjadi sebab keharaman mengadakan akad perkawinan. Bahkan al-Kasani menyatakan, bahwa pijakan utama hadanah adalah pada rasa kasih sayang, sedangkan kerabat yang memiliki hubungan mahram adalah orang yang memiliki kasih sayang paling besar. ${ }^{19}$

Meski secara prinsip fuqaha sepakat untuk mendahulukan ibu dan kerabatnya daripada ayah dan kerabatnya, namun mereka berbeda pendapat tentang penjelasan lebih rinci mengenai uruturutan para hadinab/hadin berdasarkan kemaslahatan. Kesimpulannya, urutan pengasuh dari jurusan ibu sebagai berikut:

Hanafiyah: ibu, ibunya ibu, ibunya ayah, saudara perempuan kandung, saudara perempuan ibu,anak perempuan dari saudara perempuan kandung,anak perempuan dari saudara laki-laki, saudara perempuan ayah dan asabah menurut urutan waris.

Malikiyah : ibu, nenek dari ibu, saudara perempuan ibu, nenek seayah seterusnya ke atas, saudara perempuan, saudara perempuan ayah, anak perempuan dari saudara laki-laki, orang yang diberi wasiat, dan asabab yang paling utama.

Shafi'iyyah: Ibu, ibunya ibu, ibunya ayah, saudara perempuan, saudara perempuan ibu, anak perempuan dari saudara laki-laki, anak perempuan dari saudara perempuan, saudara perempuan ayah, dan semua ahli waris asabah yang memiliki hubungan mahram dan dapat mewarisi sebagaimana Hanafiyyah.

Hanabilah : Ibu, ibunya ibu, ibunya ayah, kakek, ibunya kakek, saudara perempuan kandung, saudara perempuan seibu, saudara perempuan ibu seayah, saudara perempuan ibu sekandung, saudara perempuan ibu seibu, saudara perempuan ayah seayah, saudara perempuan ayah, saudara perempuan ibunya ibu, lalu

${ }^{19}$ Muhammad Abu Zahrah, Ahwal al-Syakhsyiyyah, 475. 
saudara perempuan ibunya ayah, saudara perempuan ayahnya ayah, anak perempuan pamannya ayah, lalu asabah terdekat. ${ }^{20}$

Sementara itu, jika anak tidak memiliki seorang pun kerabat perempuan tersebut di atas, maka hak hadanah berpindah kepada para laki-laki sesuai dengan urutan ahli waris asabah yang mahram yaitu ayah, kakek dan seterusnya ke atas, saudara-saudara laki-laki dan anak-anak mereka dan seterusnya ke bawah, saudara-saudara laki-laki ayah dan anak-anaknya mereka menurut Hanafiyyah dan selain mereka menurut yang asah dalam mazhab Syafi'i. namun, jika mereka ini tidak ada, maka hak hadanah beralih kepada zawil arbam. ${ }^{21}$

Pasal 156 Kompilasi Hukum Islam (KHI) huruf a dan b telah mengkonfirmasi ketentuan umum yang disepakati fuqaha berkaitan dengan siapa yang berhak melakukan hadanah pada anak-anak. Huruf a pasal tersebut menyatakan: anak yang belum mumayyiz berbak mendapatkan hadanabdari ibunya, sedangkan huruf $\mathrm{b}$ menyatakan : anak yang sudah mumayyiz berbak memilib untuk mendapatkan hadanabdari ayah atau ibunya. KHI juga mengatur urutan yang berhak melakukan hadanah jika ibu telah meninggal dunia. Pada huruf a pasal tersebut ada lanjutan : kecuali jika ibunya telah meninggal dunia, maka kedudukannya digantikan oleh:

1. wanita-wanita garis lurus ke atas dari ibu ;

2. ayah ;

3. wanita-wanita dalam garis lurus ke atas dari ayah ;

4. saudara perempuan dari anak yang bersangkutan;

5. wanita-wanita kerabat menurut garis ke samping dari ibu ;

6. wanita-wanita kerabat menurut garis kw samping dari ayah.

Urutan ini berbeda dengan tata urutan dari empat mazhab di atas. Meski demikian, ia memiliki banyak kemiripan dengan urutan yang ada pada mazhab Shafi'i dan mazhab Hanbali. Bedanya KHI menempatkan posisi ayah tepat berada di bawah wanita-wanita garis lurus ke atas dari ibu. KHI tidak menunggu

${ }^{20}$ Wahbah Zuhaili, Al-Figh al-Islami wa Adillatuh, V : 722.

${ }^{21}$ Ibid, 723. 
sampai habisnya pengasuh dari sisi perempuan untuk memberikan hak asuh kepada ayah. Hal ini merupakan tata pengurutan yang realistis dan lebih menjamin kemaslahatan anak asuh.

\section{Syarat-Syarat Pengasuh (Hadinah/Hadin)}

Abu Zahrah mencatat beberapa syarat yang harus dipenuhi oleh seorang hadin atau hadinah. Syarat-syarat tersebut adalah sebagai berikut :

1. Merdeka

2. Balig

3. Berakal

4. Memiliki kecakapan untuk mengatur semua urusan anak yang diasuhnya. Karena itu, ia dipandang tidak cakap jika ia sakitsakitan, sudah sangat tua atau terlalu sibuk dengan urusan lain disebabkan pekerjaan di luar rumah yang menghabiskan sebagian besar waktu siang dan malamnya. Sebab hak hadanah diberikan terutama ditujukan untuk kemaslahatan si anak dalam bidang pendidikan, pemeliharaan, dan perlindungan. Hal itu tidak bisa dilakukan dengan semua kekurangan terebut. Namun penilaian kecakapan ibu yang bekerja diserahkan kepada Pengadilan. Dalam catatan Wahbah Zuhaili, hukum yang berlaku di Mesir menegaskan, bahwa kaum perempuan yang bekerja sebagai dokter atau guru tidak kehilangan hak hadanah mereka, karena mereka mampu menangani urusan anak yang diasuhnya sendirian maupun dengan bantuan sanak kerabatnya atau orang yang menggantikan kedudukannya.

5. Dapat dipercaya (amanah) dari sudut pemeliharaan diri dan akhlaknya. Karena itu, perempuan maupun laki-laki yang rusak akhlaknya, seperti suka mabuk-mabukan dan suka berzina, tidak dipandang cakap melakukan tugas hadanah karena dikhawatirkan akhlak buruknya itu akan mempengaruhi dan menular kepada anak kecil yang diasuhnya. Ini tidak berarti bahwa perempuan yang tidak beragama dengan baik tidak berhak untuk melakukan tugas hadanah. Tugas tersebut tetap 
boleh ia lakukan asalkan akhlak buruknya tidak sampai merusak dan merugikan kemaslahatan anak tersebut sehingga menjadikannya berakhlak buruk. Dalam hal ini, ia tidak dipandang cakap bukan karena tidak memiliki agama, tetapi karena karena ia kehilangan sifat amanah di dalam dirinya dan tidak cakap melakukan hadanah. Dengan demikian, jika tidak adanya agama tidak mengakibatkan kerugian pada perilaku akhlak dan keagamaan anak, maka ia tetap dipandang cakap melakukan hadanah.

6. Tidak Murtad. Perempuan murtad dipandang tidak dapat dipercaya.

7. Tidak menempatkan anak yang diasuh pada selain kerabat karena hubungan mahram, seperti saudara perempuan seibu yang menempatkannya di kediaman ayahnya. Sebab ayahnya tersebut adalah orang asing baginya. Orang asing akan memandangnya dengan pandangan kebencian dan tidak mengasihinya sehingga ia tumbuh dalam suasana yang membenci dan tidak mengasihinya. Hal itu akan mempengaruhi akhlak dan kehidupannya di masa depan.

8. Tidak bersuami dengan selain kerabat karena hubungan mahram. Dengan demikian, hak hadanahnya tidak hilang jika ia bersuami dengan kerabat yang memiliki hubungan mahram. Karena dalam hal ini, anak kecil yang diasuh tersebut akan tumbuh dalam suasana yang penuh kasih sayang dan jauh dari kebencian. ${ }^{22}$

Ada satu syarat yang diperselisihkan fuqaha, yaitu syarat agama yang sama antara hadin dan mabdun atau syarat beragama Islam bagi yang akan melakukan hadanah. Mayoritas fuqaha, termasuk ash-Shafi'iyah dan Hanabilah berpendapat, bahwa ia harus beragama Islam. Sedangkan menurut sebagian fuqaha

22 Muhammad Abu Zahrah, Abwal al-Syakbsyiyyah, 476-477. 
lainnya, Hanafiyah dan Malikiyah, beragama Islam tidak merupakan syarat untuk melakukan hadanah terhadap anak kecil yang beragama Islam selama anak itu belum mumayyiz. Menurut mereka hadanah adalah hak ibu terhadap anaknya yang dilahirkan melalui pernikahan secara islami tidak gugur disebabkan ibu tidak beragam Islam, kecuali jika anak itu sudah mumayyiz. Dalam umur sebelum mumayyiz, seorang anak masih sangat membutuhkan kasih sayang ibu kandungnya, sebab ibu lebih mengerti dengan kebutuhannya. Dalam pandangan ini, tidak terlihat adanya kekhawatiran terpengaruhnya anak dalam umur tersebut kepada agama ibunya. karena menurut mereka anak yang berada pada umur tersebut belum mengerti sama sekali masalah agama, kecuali jika terbukti adanya kesengajaan seorang ibu untuk menyeret anaknya ke agamanya. ${ }^{23}$ Karena Abu Zahrah menegaskan bahwa hak hadanah tetap dimiliki ibu meskipun berbeda agama kecuali jika hal itu dikhawatirkan akan merusak agama anaknya. Jika ada bukti yang kuat tentang hal itu, maka hak hadanah harus dicabut dari tangannya.

Masalah yang muncul kemudian adalah sampai batas mana seorang anak asuh boleh tinggal di bawah asuhan ibu pengasuh non-muslim. Menurut Abu Zahrah, dalam hal ini ada dua keadaan, yaitu :

Pertama, ketika anak itu sudah mencapai umur mumayyiz. Pada saat itu ia sudah dapat memahami dan menalar agama sehingga agama ibunya dikhawatirkan akan mempengaruhi dirinya ketika ia melihat sang ibu melakukan ritual-ritual agamanya.

Kedua, ketika anak belum mencapai umur mumayyiz, tetapi ada bukti kuat bahwa ibunya telah mengajarkan agamanya kepada anaknya, dan membiasakan anak itu dengan kebiasaan-kebiasaan agamanya. Dalam hal ini, hak hadanah harus dicabut darinya, karena ia sudah tidak dapat dipercaya dalam urusan agama anak, padahal amanah merupakan syarat dalam melakukan hadanah. ${ }^{24}$

Pasal-pasal Undang-Undang Perkawinan dan KHI tidak mengatur masalah perbedaan agama antara pengasuh dan anak asuh. Namun keduanya memberikan tekanan yang kuat terhadap

23 Satria Effendi M. Zein, Problematika Hukum Keluarga Islam Kontemporer, 174.

${ }^{24}$ Muhammad Abu Zahrah, Ahwal al-Syakhsyiyyah, 477. 
syarat kedua, yaitu dapat dipercayanya pengasuh dalam urusan pemeliharan dan pendidikan akhlak anak asuhnya. Pengadilan Agama diberi wewenang untuk mencabut hak hadanah dari pemegang hadanah yang tidak amanah, baik dalam mengurusan keperluan hidup sehar-hari anak asuhnya atau karena ia berperilaku buruk sekali yang dikhawatirkan akan mempengaruhi perilau si anak. Dalam masalah perbedaan agama, Pengadilan Agama perlu menimbang apakah perbedaan agama tersebut berdampak membawa kemaslahatan untuk anak asuh atau tidak. Jika perbedaan itu terbukti dapat merusak diri anak, maka pengadilan dapat menetapkan, bahwa pengasuh dipandang tidak amanah. Meminjam pendapat Abu Zahrah, hak hadanah dapat dicabut darinya kemudian mengalihkan kepada kerabat yang lain yang memiliki hak hadanah juga.

Pasal 49 ayat 1 Undang-Undang No.1 Tahun 1974 Tentang Perkawinan menyatakan:

Salah seorang atau kedua orang tua dapat dicabut kekuasaannya terhadap anak atau lebih untuk waktu tetentu atas permintaan orang tua yang lain, keluarga dari garis lurus ke atas dan saudara kandung yang telab dewasa atau pejabat yang berwenang, dengan keputusan Pengadilan dalam hal-hal:

1. ia sangat melalaikan kewajiban terbadap anaknya;

2. ia berkelakuan buruk sekali.

Pasal tersebut kemudian dikuatkan oleh KHI pasal 156 huruf c yang menyatakan: apabila pemegang hadanabternyata tidak dapat menjamin keselamatan jasmani dan rohani anak, meski pun biaya nafkah dan badanabtelah dicukupi, maka atas permintaan kerabat yang bersangkutan Pengadilan Agama dapat memindabkan hake hadanabkepada kerabat lain yang mempunyai bak hadanahpula.

\section{Sebab-Sebab Putusnya Hak Hadanah}

Berdasarkan syarat-syarat di atas, maka seorang pemegang hak hadanah akan kehilangan hak jika melakukan hal-hal tertentu. Menurut pendapat Malikiyah yang sebagian besarnya disepakati oleh fuqaha lain, ada empat sebab yang menggugurkan hak hadanah, yaitu : 
Pertama, jika pengasuh bepergian sangat jauh atau ke wilayah yang sangat mengkhawatirkan keamanan dirinya tanpa membawa serta anak yang diasuhnya sehingga tidak memungkinkan untuk mengunjungi anak itu di hari itu. hal ini disepakati tiga mazhab lainnya.

Kedua, jika pengasuh tertimpa penyakit gila, lepra atau baros. Pendapat ini disepakati oleh Hanabilah.

Ketiga, jika pengasuh memperlihatkan akhlak yang tercela, kurang memperhatikan masalah agama anak asuh dan kurang memberikan perlindungan kepadanya sehingga kemaslahatan anak terabaikan. Hal ini disepakati fuqaha lainnya.

Keempat, jika ibu pengasuh menikah dengan laki-laki lain. ${ }^{25}$

Selanjutnya, jika sebab-sebab yang menggugurkan hak hadanah tersebut telah hilang dari diri pengasuh, maka pertanyaan yang muncul adalah apakah hak tersebut bisa kembali dimiliki oleh pengasuh. Dalam hal ini ada 2 pendapat di kalangan fuqaha, yaitu:

Pertama, pendapat yang masyhur dalam mazhab Maliki menyatakan, bahwa jika gugurnya hak hadanah disebabkan alasan yang bisa diterima (uzur), seperti sakit, tempat yang kurang aman, bepergian untuk melaksanakan ibadah haji, lalu uzur tersebut hilang karena ia telah sembuh, tempat telah aman, dan ia sudah datang dari bepergian haji, maka hak itu kembali kepadanya. Sebab yang menggugurkan hak tersebut adalah uzur yang bisa diterima syara' (idtirary), bukan uzur ikhtiyary, yang merupakan kemauannya sendiri.

Kedua, jumhur fuqaha menegaskan bahwa jika hak hadanah gugur disebabkan halangan tertentu, lalu halangan itu hilang, maka hak tersebut kembali kepada pemiliknya baik halangannya itu bersifat idtirary maupun ikhtiyary seperti menikah, bepergian dan berakhlak tercela, karena halangan tersebut telah hilang. ${ }^{26}$

\section{Batas Masa Hadanah}

Sebagian fuqaha, Ahmad dan asy-Syafi'i menyatakan, bahwa ketika anak telah mencapai umur tamyiz, maka si anak baik laki-laki maupun perempuan diberi pilihan antara tinggal bersama ayah atau

25 Wahbah Zuhaili, Al-Figh al-Islami Wa Adillatuh, V : 730-1.

26 Ibid, 732. 
ibunya untuk pengasuhan selanjutnya. Sebab maksud utama hadanah adalah memelihara anak. Sementara anak yang sudah tamyiz lebih mengetahui kemaslahatan dirinya. Sebagian ulama lainnya, Malik dan Abu Hanifah menyepakati, bahwa hak pilih itu tidak diberikan kepada anak. Keduanya berbeda pendapat dalam penyelesaiannya. Abu Hanifah berpendapat, bahwa jika si anak telah dapat hidup mandiri, baik dalam berpakaian, makan dan membersihkan badannya, maka ayah lebih berhak atasnya, sebab ayah lebih kuat melakukan perlindungan dan lebih mampu membimbing anak yang sudah balig. Sedangkan Malik berpendapat, bahwa ibu yang lebih berhak sampai ia mencapai umur balig pada anak laki-laki dan sampai menikah bagi anak perempuan. $^{27}$

Pada dasarnya, pelaksanaan hak hadanah berakhir ketika anak yang diasuh telah mencapai umur di mana ia telah mampu mandiri tanpa memerlukan bantuan kaum perempuan. Akhir masa hadanah tersebut bagi anak laki-laki, berawal ketika ia sudah mampu makan sendiri, minum sendiri, memakai baju sendiri. Sedangkan bagi anak perempuan, hak hadanah ini berakhir ketika ia mencapai umur balig, yaitu ketika ia telah mengalami menstruasi. Pendapat di atas merupakan pendapat dari fuqaha Mutaqaddimin. Menurut Abu Zahrah, pendapat mereka ini didasarkan pada kenyataan yang ada pada kemampuan anak, tanpa melihat umurnya. Karena itu, fuqaha Mutaakhirin kemudian memutuskan, bahwa batas akhir hadanah harus berdasarkan umur untuk menghindari perselisihan. Dengan demikian, jika ada perbedaan pendapat, maka akan mudah penyelesaiannya karena ada patokan umur yang jelas. Al-Khassaf menjadikan batas akhir masa hadanah bagi anak laki-laki ketika sudah berumur tujuh tahun, karena merupakan minimal umur tamyiz. Ketika anak laki-laki telah mencapai umur ini, maka ia membutuhkan orang yang membimbingnya dan menuntunnya berkaitan dengan adat kebiasaan kaum laki-laki. Sebagian yang lain menetapkan umur sembilan tahun. Sedangkan batas akhir masa hadanah bagi anak perempuan adalah umur sembilan tahun, karena ia memerlukan

27 Amir Syarifuddin, Hukum Perkawinan Islam di Indonesia, 331. 
pemeliharaan dari kaum perempuan agar dibimbing mengenai kebiasaan-kebiasaan kaum perempuan. Setelah itu perempuan dipandang butuh penjagaan dan perlindungan. Kaum laki-laki, dalam hal ini, dianggap lebih mampu. Sebagian yang lain menetapkan umur sebelas tahun sebagai masa akhir hadanah. ${ }^{28}$

Menurut Abu Zahrah, kebiasaan yang berlaku di Mesir pada awalnya mengikuti jalan pikiran al-Khassaf. Hingga kemudian terbitundang-undang pada tahun 1929 yang menegaskan adanya batas minimal dan batas maksimal untuk masa pelaksanaan hadanah. Bagi anak laki-laki berkisar antara umur tujuh sampai sembilan tahun. Sedangkan bagi anak perempuan berkisar antara sembilan sampai sebelas tahun. Penentuan umur tersebut diserahkan sepenuhnya kepada hakim pengadilan, karena keadaan jasmani dan rohani anak-anak berbeda-beda. Boleh jadi anak yang keadannya lemah akan memerlukan masa pengasuhan yang lebih lama oleh ibunya dan sebaliknya. Dengan demikian, yang menjadi ukuran penentuan umur adalah kemaslahatan si anak. ${ }^{29}$

Berdasarkan wacana yang berkembang di atas, dapat disimpulkan adanya pemilahan batas akhir masa hadanah, yaitu :

Pertama, sejak bayi lahir hingga telah umur mumayyiz. Pada masa ini, secara umum pengasuhan diserahkan pada ibu sebagai pemegang perwalian pemeliharaan dan pendidikan anak. Diistilahkan dengan hadanah atau kafalah.

Kedua, sejak anak berumur tamyiz sampai ia dewasa. Pada saat ini, pengasuhan anak diserahkan pada bapak selaku pemegang perwalian diri anak (Wakalah).

Baik Undang-Undang Perkawinan maupun KHI, tidak memilah antara umur mumayyiz dan umur dewasa. Penetapan umur mumayyiz dan umur dewasa diserahkan sepenuhnya kepada kebijakan hakim Pengadilan Agama, keduanya juga tidak membedakan antara pemegang hadanah dan pemegang tugas wakalah.

Pasal 45 ayat (2) Undang-Undang No. 1 Tahun 1974 Tentang Perkawinan menetapkan, bahwa kewajiban kedua orang tua dalam memelihara dan mendidik anak-anaknya adalah sampai

28 Muhammad Abu Zahrah, Ahwal al-Syakhsyiyyah, 483-4.

29 Ibid. 
mereka sudah bisa berdiri sendiri. Pasal ini berbicara tentang perwalian dalam pendidikan dan pemeliharaan anak, atau hadanah .

Lebih dari itu pasal 47 ayat (1) menegaskan bahwa anak yang belum berumur 18 tahun atau belum menikah, tetap berada di bawah kekuasaan orang tuanya selama mereka tidak dicabut dari kekuasaannya. Dan ayat (2) menyatakan, bahwa orang tua mewakili anak tersebut mengenai segala perbuatan hukum di dalam dan di luar Pengadilan. Pasal ini berkaitan dengan perwalian terhadap diri anak.

Pasal 48 menyatakan, bahwa orang tua tidak diperbolehkan memindahkan hak atau menggadaikan barang-barang tetap yang dimiliki anaknya yang belum berumur 18 (delapan belas) tahun atau belum pernah melangsungkan perkawinan, kecuali apabila kepentingan anak itu menghendakinya. Pasal ini berkaitan dengan perwalian terhadap harta anak.

Pasal-pasal tentang perwalian terhadap diri anak dan perwalian terhadap harta anak mencantumkan umur 18 tahun. Sementara pada perwalian terhadap pemeliharaan dan pendidikan anak, tidak mencantumkan umur 18 tahun. Saya kira ini bukan kesengajaan Undang-Undang Perkawinan untuk memilah dan membedakan batas akhir dari ketiga perwalian tersebut. Karena itu, kita bisa menganalogikan batas akhir hadanah kepada dua bentuk perwalian yang lain, yaitu 18 tahun. Dengan demikian, kita bisa menetapkan, bahwa batas akhir hadanah adalah ketika anak berumur 18 tahun, sudah menikah, atau bisa berdiri sendiri. Hal ini berarti Undang-Undang Perkawinan menegaskan, bahwa tugas memegang hadanah dan sekaligus wakalah diemban oleh pemegang hadanah. Sedangkan semua biaya yang menyangkut hak tersebut menjadi tanggung jawab ayah menurut kemampuannya, sekurang-kurangnya sampai anak tersebut dapat mengurus diri sendiri (21 tahun) sesuai dengan pasal 156 huruf d. Ketentuan ini merupakan hasil ijtihad para pembuat hukum kita yang sesuai dengan kemaslahatan anak. Kemaslahatan tersebut disesuaikan dengan perkembangan dan perubahan zaman serta kepastian hukum. 


\section{Hak Mengunjungi Anak yang Berada di Bawah Asuhan Pihak Lain}

Fuqaha sepakat bahwa Hak untuk melihat dan mengunjungi anak bagi salah atu dari kedua orang tua yang tidak sedang mengasuh, diakui oleh syara' dalam rangka mengikat tali silaturrahim. Namun, dalam perinciannya ada beberapa perbedaan pendapat.

Hanafiyyah berpendapat, jika anak berada di bawah asuhan ibu, maka ayah boleh melihatnya dengan cara membawanya ke tempat yang memungkinkan ayah dapat melihatnya setiap hari. Jika anak diasuh ayahnya, karena hak hadanah Ibu digugurkan atau karena habisnya masa hadanah, maka ibu boleh melihatya dengan cara membawanya ke tempat yang memungkinkan untuk dapat melihatnya setiap hari. Batas maksimalnya adalah satu minggu.

Menurut Malikiyah, ibu berhak melihat anak-anaknya yang masih kecil sekali dalam sehari dan anak-anaknya yang sudah besar sekali dalam seminggu. Hak ibu sama dengan ayah dalam hal melihat anak sebelum mereka mencapai umur pembelajaran. Adapun setelah masuk umur pendidikan dan pengajaran, maka ayah berhak untuk menemani anaknya belajar dari waktu ke waktu.

Shafi'iyyah berpendapat bahwa jika anak yang sudah mumayyiz memilih ayahnya, maka ibunya boleh mengunjunginya. Namun, ayah boleh melarang anak perempuan untuk mengunjungi ibunya demi untuk melindungi sang anak. Sebaiknya, ibu yang mengunjungi si anak perempuan. Ayah tidak boleh melarang kunjungan ibu terhadap anaknya, baik laki-laki maupun perempuan. Namun, kunjungan tersebut tidak boleh terlalu lama. Ia boleh memilih antara memberi kesempatan ibunya masuk ke rumahnya atau mempersilahkan anaknya untuk keluar rumah dalam rangka menemui ibunya. Jika anak itu, baik laki-laki maupun perempuan sakit, maka ibunya lebih utama untuk merawatnya. Sebab ibu lebih sabar dibandingkan ayah. Perawatan bisa dilakukan, baik di rumah ayah atau ibunya asalkan diizinkan ayahnya.

Hanabilah senada dengan Shafi'iyyah, bahwa jika anak itu memilih ayahnya, maka ia berada di bawah asuhannya, baik di siang hari maupun malam hari. Ayah tidak boleh melarang ibunya untuk 
mengunjunginya atau merawatnya. Jika ia memilih ibunya, maka ia berada di sampingnya di malam hari dan di samping ayahnya di siang hari untuk mengajari dan mendidiknya. Sedangkan anak perempuan harus berada di bawah asuhan ayahnya sampai ia menikah. Salah satu dari orang tuanya tidak boleh melarang kunjungan yang lain kepada anak, sebab hal itu berarti memutus ikatan silaturrahim. Dengan syarat kunjungan itu tidak lama. Jika anak itu sakit, maka ibu lebih berhak untuk merawatnya di rumah ayah, karena ibu membutuhkannya. ${ }^{30}$

\section{Biaya Hadanah}

Pada dasarnya, hadanah merupakan salah satu bentuk pengampuan (wilayah) dan penguasaan (sultanah) di mana perempuan dipandang lebih layak untuk melakukannya. Seorang ibu lebih diutamakan daripada ayah , meski pun segala biaya proses hadanah tetap dibebankan kepada ayah. ${ }^{31}$ Yang menjadi perdebatan di kalangan fuqaha adalah apakah perempuan yang mengasuh anak mendapatkan upah atas jasa hadanah yang telah ia berikan. Pendapat fuqaha dalam hal ini terbagi menjadi dua pendapat, yaitu:

Pertama, jumhur fuqaha berpendapat, bahwa pengasuh anak, baik ibunya sendiri maupun yang lain, tidak berhak mendapatkan upah, karena ibu sudah mendapatkan nafkah dari ayah jika ia masih resmi menjadi isterinya. Sedangkan selain ibu, juga sudah mendapatkan nafkah dari ayah anak tersebut. Dengan demikian, jika selain ibu memerlukan tempat tinggal atau pembantu untuk memasak atau mencuci, maka segala biaya untuk keperluan itu harus disediakan. Penyediaan biaya tersebut dibebankan pada harta anak asuh itu sendiri, jika ia punya harta, karena nafkah dirinya diambil dari hartanya sendiri. Upah hadanah termasuk nafkah dirinya. Namun, jika ia tidak memiliki harta, maka upah hadanah harus disediakan oleh orang yang berkewajiban untuk menafkahinya. Ayah harus menanggungnya jika ia masih hidup dan mampu secara ekonomi. Jika ia tidak memiliki ayah atau ayahnya

30 Wahbah Zuhaili, Al-Fiqh al-Islami Wa Adillatuh, V : 740-1

${ }^{31}$ Abu Hamid al-Gazali, Al-Wajiz fi Fiqh Mazhab al-Imam asy-Syafi'i, (Beirut : Dar al-Fikr, 1994), 240. 
ada, tetapi tidak mampu secara ekonomi, maka beban itu harus ditanggung oleh kerabat-kerabat dekatnya.

Kedua, Hanafiyah berpendapat, bahwa pengasuh anak tidak berhak mendapatkan upah hadanah jika ia masih terikat hubungan perkawinan selaku isteri atau masih menjalani masa iddah, baik dari talak raj'i maupun talak bain. Ia juga tidak berhak atas upah menyusui, karena keduanya merupakan kewajiban yang ditetapkan oleh agama, sementara nafkah yang ia terima di sela-sela ikatan perkawinan dan iddah sudah mencukupi untuk biaya hadanah. Sebenarnya, upah hadanah itu bukan merupakan imbalan murni, akan tetapi mirip dengan upah menyusui bagi ibu sebagai nafkah dan biaya hidup. Nafkah itu merupakan hak yang diterimanya selaku isteri, meskipun ia masih dalam masa iddah. Ibu tidak boleh menerima dua nafkah dari satu orang pada satu waktu, meski pun ada beberapa sebab yang berbeda. Dengan demikian, jika masa iddah telah berakhir, ibu berhak mendapatkan upah hadanah, karena upah itu maknanya sudah bergeser menjadi upah atas pekerjaan yang dilakukannya. Adapun jika pengasuh anak itu selain ibu, maka ia berhak mendapatkan upah hadanah sebagai imbalan atas pekerjaan pengasuhan anak yang dilakukannya. Upah itu bukan upah menyusui dan bukan pula nafkah si anak. Jadi di sini, ada tiga kewajiban yang harus dibedakan: yaitu upah hadanah, upah menyusui, dan nafkah anak. ${ }^{32}$

KHI Pasal 156 huruf d menetapkan, bahwa semua biaya yang menyangkut hak tersebut menjadi tanggung jawab ayah menurut kemampuannya, sekurang-kurangnya sampai anak tersebut dapat mengurus diri sendiri (21 tahun). Bahkan, kedua orang tua masih berkewajiban untuk memberi biaya pemeliharaan kepada anak-anaknya meskipun ia dicabut dari kekuasaannnya sesuai pasal 49 ayat (2) Undang-Undang Perkawinan.

\section{Penutup}

Ketika terjadi perceraian antara suami dan isteri, di samping menimbulkan terlepasnya ikatan perkawinan beserta hubunganhubungan hukum hukum yang terkait dengannya, juga

32 Wahbah Zuhaili, Al-Fiqh al-Islami Wa Adillatuh, V : 734-5. Dan lihat juga Muhammad Abu Zahrah, Ahwal al-Syakhsyiyyah, 479-80. 
mengakibatkan dampak yang negatif terhadap pihak ketiga, yaitu anak-anak. Mereka tidak lagi memiliki orang tua yang utuh sehingga masa depan mereka diliputi dengan ketidakpastian. Atas dasar itu, hukum Islam menetapkan serangkian ketentuanketentuan hukum dalam rangka melindungi dan mempertahankan kepentingan dan kemaslahatan anak-anak korban perceraian. Hukum Islam menetapkan, bahwa kewajiban orang tua terhadap anak dalam rangka memelihara dan melindungi kepentingan mereka tidak terbatas pada saat perkawinan mereka masih utuh, tetapi kewajiban itu terus berlangsung meski perkawinan mereka telah putus. Kewajiban tersebut berlaku sampai anak-anak mampu hidup mandiri atau sudah menikah. Secara prinsip, Islam memang memberikan prioritas kepada ibu untuk mengasuh dan mendidik anak-anak, karena ibu dipandang lebih telaten, lebih sabar dan lebih memiliki kasih sayang dibanding ayah. Namun, ketentuan itu tidak kaku. Islam selalu berpihak kepada kepentingan anak-anak. Untuk itu, Islam menetapkan beberapa syarat penting yang harus dimiliki oleh orang yang hendak menjadi pengasuh anak-anak: yaitu, memiliki sikap amanah dan memiliki kecakapan. Syarat amanah meliputi sikap moral yang baik dan tidak merusak agama anak. Syarat kecakapan menuntut kesediaan pengasuh meluangkan waktu untuk anak. Atas dasar itu, ayah atau laki-laki, bisa menggantikan posisi ibu jika terbukti ibu memiliki tabiat buruk yang dikhawatirkan akan ditiru oeh anak-anaknya, atau jika terbukti tidak cakap dalam mengasuh anak-anak karena kesibukan pekerjaan yang menghabiskan seluruh waktu sehingga ia menelantarkan pengasuhan anaknya, atau ibu tidak memiliki penghasilan cukup untuk mengasuh anaknya dalam arti luas. Sengketa mengenai pengasuhan anak biasanya berkisar masalah amanah dan kecakapan orang tua terhadap pengasuhan anaknya. Untuk itu, penentuan amanah atau tidaknya seorang pengasuh ditetapkan di dalam Pengadilan Agama.

\section{Daftar Pustaka}

Abu Dawud. Sunan Abu Dawnd. Juz II, Libanon : Dar al-Kutub al'Ilmiyyah, 1996. 
Abu Hamid al-Gazali. Al-Wajiz fi Fiqh Mazhab al-Imam asy-Syafi'i, Beirut : Dar al-Fikr, 1994.

Ahmad Rofiq. Hukum Perdata Islam di Indonesia, Jakarta : PT. Rajagrafindo Persada, 2015.

Amir Syarifuddin. Hukum Perkawinan Islam di Indonesia, Jakarta : Prenada Media Group, 2006.

Jalaluddin al-Suyuti. Syarb Sunan an-Nasa'i, Beirut : Dar al-Kutub alIlmiyyah, 1988), V.

Kamal Muchtar. Asas-asas Hukum Islam Tentang Perkawinan, Jakarta : Bulan Bintang, 2004

Muhammad Abu Zahrah. Abwal asy-Syakhsyizayyah, Mesir : Matba'ah as-Sa'adah, 1957.

Muhammad Abu Zahrah. Tanzim al-Islam li al-Mujtama', Mesir : Dar al-fikr al-'Arabiy,t.t..

Satria Effendi M. Zein. Problematika Hukum Keluarga Islam Kontemporer, (Jakarta : Prenada Media, 2004.

Al-Shan'ani. Subul al-Salam, juz 3, Kairo : Dar Ihya al-Turats al'Araby, 1379 H/1960 M.

Sudarsono. Kamus Hukum, Jakarta : Rineka Cipta, 1992.

Wahbah al-Zuhaili. Al-Figh al-Islami wa Adillatuh, Damsyiq : Dar alFikr, 1989, VII. 